Tetrahedron

journal homepage: www.elsevier.com

\title{
Vanadium-Catalyzed Green Oxidation of Benzylic Alcohols in Water under Air Atmosphere
}

\author{
Kuniaki Marui, ${ }^{\dagger}$ Yuuki Higashiura, ${ }^{\dagger}$ Shintaro Kodama, ${ }^{\dagger}$ Suguru Hashidate, ${ }^{\dagger}$ Akihiro Nomoto, ${ }^{\dagger}$ Shigenobu \\ Yano, ${ }^{\star}$ Michio Ueshima, ${ }^{\dagger}$ and Akiya Ogawa*,† \\ † Department of Applied Chemistry, Graduate School of Engineering, Osaka Prefecture University, 1-1 Gakuen-cho, Naka-ku, Sakai, Osaka, Japan. \\ $\$$ Graduate School of Materials Sience, Nara Institute of Science and Technology, 8916-5 Takayama, Ikoma, Nara, Japan. \\ Corresponding author. Tel.: +81-72-254-9290; fax: +81-72-254-9290; e-mail: ogawa@chem.osakafu-u.ac.jp
}

\section{ARTICLE INFO}

\section{Article history:}

Received

Received in revised form

Accepted

Available online

Keywords:

Oxidaiton

Vanadium catalyst

Water solvent

Gram-scale

Air condition

\section{Introduction}

The oxidation of alcohols to aldehydes and ketones is one of the most important synthetic transformations for the organic chemist with respect to the useful intermediates obtained for the preparation of more complex organic compounds. ${ }^{1}$ Conventionally, stoichiometric amounts of heavy metals (e.g., chromium(VI)) are used as oxidants. Therefore, the oxidation of alcohols using catalytic amounts of metal complexes is a highly attractive prospect from the viewpoint of green chemistry principles, ${ }^{2}$ in which the following reaction characteristics are desired: (1) the use of earth-abundant transition metals in terms of sustainability and cost; (2) use of molecular oxygen $\left(\mathrm{O}_{2}\right)$ as a terminal oxidant, where water is the only by-product; (3) use of water in place of organic solvents due to its low cost and inflammability, and great abundance. ${ }^{8}$ However, examples of metal complex-catalyzed oxidations of alcohols with $\mathrm{O}_{2}$ using water as the solvent are still rare. ${ }^{9}$ Precious metals (e.g., Au, Ru, and $\mathrm{Pd}$ ), high-pressure $\mathrm{O}_{2}$ or air, and a stoichiometric amount of base are often required.

Vanadium is a relatively abundant element, ranking among the top 20 elements occurring in the earth's crust. The oxidative properties of pentavalent vanadium are well known. ${ }^{10}$ Recent studies have focused on the development of vanadium catalysts for the oxidation of alcohols with $\mathrm{O}_{2},{ }^{11}$ nonetheless, no reports are known to exist of an efficient vanadium catalytic system for aerobic oxidation of alcohols using water as the only solvent under atmospheric conditions.
Recently, we have reported the aerobic oxidation of benzyl alcohols catalyzed by $(\mathrm{VO})_{4}(\mathrm{hpic})_{4}$ or $\mathrm{VO}(\mathrm{Hhpic})_{2}$, which are synthesized from $\mathrm{VOSO}_{4}$ and 3-hydroxypyridine-2-carboxylic acid $\left(\mathrm{H}_{2}\right.$ hpic) ${ }^{12(\mathrm{a}) \text {, (b) }}$ Recyclability was observed in $(\mathrm{VO})_{4}(\mathrm{hpic})_{4}$, while $\mathrm{VO}(\mathrm{Hhpic})_{2}$ was noted to have relatively high catalytic activity (Scheme 1).

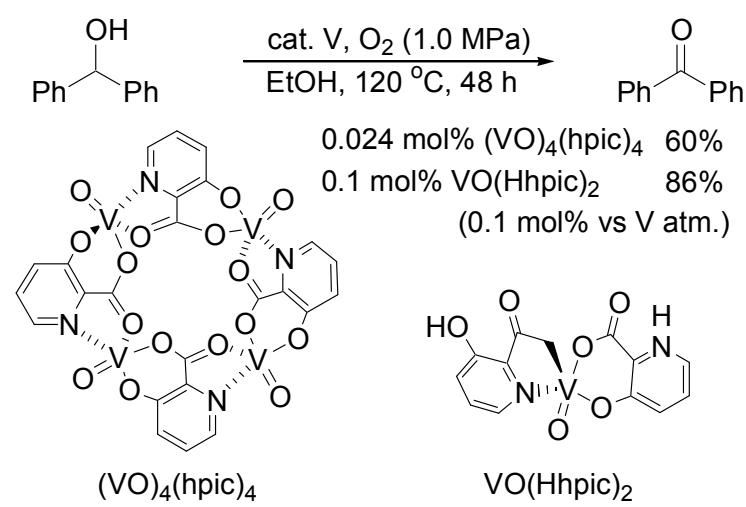

Scheme 1 Oxidation of benzhydrol using $\mathrm{VO}(\mathrm{Hhpic})_{2}$ or $(\mathrm{VO})_{4}(\text { hpic })_{4}$

Opportunely, we also found that $\mathrm{VO}(\mathrm{Hhpic})_{2}$ could also oxidize benzylamines to the corresponding imines with high selectivity using an ionic liquid solvent under an atmosphere of $\mathrm{O}_{2}(0.1 \mathrm{MPa})$, also with good recyclability (Scheme 2). ${ }^{12(\mathrm{c})}$ 


$$
\mathrm{Ph} \frown \mathrm{NH}_{2} \underset{\text { lonic liruid, } 120^{\circ} \mathrm{C}, 6 \mathrm{~h}}{\stackrel{\mathrm{VO}(\text { Hhpic })_{2}, \mathrm{O}_{2}(0.1 \mathrm{MPa})}{\longrightarrow}} \mathrm{Ph} \frown \overbrace{\mathrm{Nh}} \widehat{\mathrm{Ph}}_{\mathrm{P}}
$$

Scheme 2 Oxidation of benzylamine using recyclable vanadium catalyst $\mathrm{VO}(\mathrm{Hhpic})_{2}$ in ionic liquid

$$
\text { catalyst, } \mathrm{H}_{2} \mathrm{O}_{2}(1.6 \mathrm{mmol})
$$

Scheme 3 Oxidation of benzhydrol using heterotetranuclear complexes

Furthermore, the oxidation of alcohols with $\mathrm{H}_{2} \mathrm{O}_{2}$ using heterotetranuclear complexes bearing bipyridyl ligands in water as solvent was already repoeted (Scheme 3 ). ${ }^{12(d)}$

Herein, we report the efficient oxidation of benzyl alcohol derivatives using an oxovanadium-2,2'-bipyridyl complex using water as the sole solvent under an atmosphere of $\mathrm{O}_{2}$; the ligand 4,4'-di-tert-butyl-2,2'-bipyridyl (4,4'-t-Bubpy) provides the greatest yields of oxidation products. ${ }^{12(\mathrm{e})}$ Furthermore, this reaction system could also be used for gram-scale oxidation reactions under atmospheric pressure in air. To the best of our knowledge, this is the first report of an efficient catalytic system employing vanadium for the aerobic oxidation of alcohols using water as the only solvent under atmospheric conditions. We have also forcused on using $\mathrm{H}_{2} \mathrm{O}$ as safer and abundant.

\section{Results and discussion}

Firstly, to determine the most effective ligand for catalysis, as preliminary experimental, a series of $\mathrm{H}_{2}$ hpic derivatives were screened (Table 1, entries 1-5). It was found that the pyridine unit was essential for the useful catalytic activity of vanadium (entry 5). An examination of several pyridine derivatives revealed that the functional group identity on the pyridine unit affects reaction efficiency to some extent (entries 6-9). Next, the bidentate 2,2'-bipyridyl ligand consisting of two pyridine units was applied to this oxidation. In entry 11, the yield of the corresponding ketone was found to have increased compared with entry 5. More interestingly, an over-oxidation product (benzoic acid) was observed when 2,2'-bipyridyl was used (entry 10). These data suggest that a bidentate ligand is more efficient than monodentate ligand in the oxidation, and that the bipyridyl unit in particular appears to be the most effective for the oxidative activity of vanadium.

A number of oxovanadium compounds including $\mathrm{VO}(\mathrm{Hhpic})_{2}$, previously identified as an oxidant with good catalytic activity (cf. Scheme 2), were examined in the oxidation of benzhydrol (1a) in water under an $\mathrm{O}_{2}$ atmosphere $(0.1 \mathrm{MPa})$ at $90{ }^{\circ} \mathrm{C}$, and resulting products were identified by NMR. Unfortunately, $\mathrm{VO}(\text { Hhpic })_{2}$ and $\mathrm{VOSO}_{4}$ were not effective under the reaction conditions (Table 2, entries 2, 3). Also, the addition of $\mathrm{H}_{2}$ hpic was found to be ineffective for the $\mathrm{VOSO}_{4}$-catalyzed reaction (entry 4). In sharp contrast, when 4,4'-t-Bubpy was used as a

\begin{tabular}{|c|c|c|c|c|c|}
\hline $\mathrm{Ph} \widehat{\mathrm{C}}$ & \multicolumn{2}{|c|}{$\begin{array}{l}\mathrm{VOSO}_{4}(2 \mathrm{~mol} \%), \\
\mathrm{O}_{2}(1.0 \mathrm{MPa})\end{array}$} & and (4 & h & \\
\hline Entry & Ligand & $\begin{array}{l}\text { Yield } \\
(\%)^{a}\end{array}$ & Entry & Ligand & $\begin{array}{l}\text { Yield } \\
(\%)^{a}\end{array}$ \\
\hline 1 & $\mathrm{COC}$ & 48 & 7 & & 38 \\
\hline 2 & c & 12 & 8 & & 49 \\
\hline 3 & & 7 & 9 & & 7 \\
\hline 4 & $\mathrm{COC}$ & 5 & 10 & & $17(29)$ \\
\hline 5 & & $40(9)$ & 11 & $-N$ & 55 \\
\hline 6 & & 55 & & & \\
\hline
\end{tabular}

Table 1 Examination of ligand effects on vanadium-catalyzed oxidation

${ }^{a}$ Determined by ${ }^{1} \mathrm{H}$ NMR. Yield of benzoic acid is shown in parentheses.

Table 2 Vanadium catalyst activities for oxidation of

\begin{tabular}{|c|c|c|c|c|}
\hline Entry & Catalyst & Ligand & $\begin{array}{l}\text { Time } \\
\text { (h) }\end{array}$ & $\begin{array}{c}\text { Yield of } \mathbf{2 a} \\
(\%)^{b}\end{array}$ \\
\hline 1 & None & None & 3 & N.D. \\
\hline 2 & $\mathrm{VOSO}_{4}$ & None & 3 & trace \\
\hline 3 & $\mathrm{VO}(\mathrm{Hhpic})_{2}$ & None & 3 & N.D. \\
\hline 4 & $\mathrm{VOSO}_{4}$ & $\mathrm{H}_{2}$ hpic & 3 & trace \\
\hline 5 & {$\left[\mathrm{VO}(t-\mathrm{Bubpy})_{2}\right] \mathrm{SO}_{4}$} & None & 3 & 43 \\
\hline 6 & $\mathrm{VOSO}_{4}$ & 4,4'-t-Bubpy & 3 & 47 \\
\hline 7 & $\mathrm{VOSO}_{4}$ & 4,4'-DCbpy & 3 & 2 \\
\hline 8 & $\mathrm{VOSO}_{4}$ & 6,6'-Mebpy & 3 & N.D. \\
\hline 9 & $\mathrm{VOSO}_{4}$ & 4,4'-t-Bubpy & 6 & 83 \\
\hline 10 & $\mathrm{VOSO}_{4}$ & 5,5'-Mebpy & 6 & 76 \\
\hline 11 & $\mathrm{VOSO}_{4}$ & 4,4'-Mebpy & 6 & 33 \\
\hline 12 & $\mathrm{VOSO}_{4}$ & 4,4'-MeObpy & 6 & 19 \\
\hline 13 & $\mathrm{VOSO}_{4}$ & 4,4'-Phbpy & 6 & trace \\
\hline 14 & $\mathrm{VOSO}_{4}$ & Phen & 6 & 22 \\
\hline 15 & $\mathrm{VOSO}_{4}$ & Bpy & 6 & 17 \\
\hline
\end{tabular}
benzhydrol $^{a}$

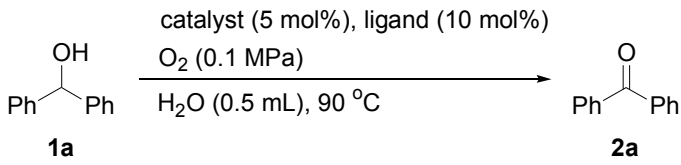

${ }^{a}$ Reaction conditions: catalyst $(0.005 \mathrm{mmol})$, ligand $(0.01 \mathrm{mmol}), 1 \mathrm{a}(0.1$ mmol $), \mathrm{H}_{2} \mathrm{O}(0.5 \mathrm{~mL}), \mathrm{O}_{2}(0.1 \mathrm{MPa}), 90{ }^{\circ} \mathrm{C} .{ }^{b}$ Determined by ${ }^{1} \mathrm{H}$ NMR. N.D.: Not detected. 4,4'-DCbpy: 2,2'-bipyridine-4,4'-dicarboxylic acid. 6,6'-Mebpy: 6,6'-dimethyl-2,2'-bipyridyl. 5,5'-Mebpy: 5,5'-dimethyl-2,2'-bipyridyl. 4,4'Mebpy: 4,4'-dimethyl-2,2'-bipyridyl. 4,4'-MeObpy: 4,4'-dimethoxy-2,2'bipyridyl. 4,4'-Phbpy: 4,4'-diphenyl-2,2'-bipyridyl. Phen: phenanthroline. Bpy: 2,2'-bipyridine.

ligand, the oxidation of 1a proceeded successfully in moderate yield (entry 5). The addition of 4,4'-t-Bubpy was also effective 
Table 3 Vanadium-catalyzed oxidation of benzhydrol derivatives under $\mathrm{O}_{2}$ atmosphere in water ${ }^{a}$

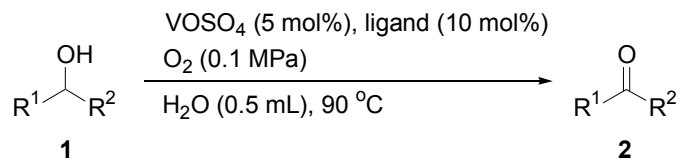

\begin{tabular}{ccccccc}
\hline Entry & $\mathrm{R}^{1}$ & $\mathrm{R}^{2}$ & & Time $(\mathrm{h})$ & \multicolumn{2}{c}{ Yield of $\mathbf{2}(\%)^{b}$} \\
\hline 1 & $\mathrm{Ph}$ & $\mathrm{Ph}$ & $\mathbf{1 a}$ & 6 & $\mathbf{2 a}$ & $(87)$ \\
2 & $4-\mathrm{MeOC}_{6} \mathrm{H}_{4}$ & $\mathrm{Ph}$ & $\mathbf{1 b}$ & 8 & $\mathbf{2 b}$ & 83 \\
3 & $4-\mathrm{BrC}_{6} \mathrm{H}_{4}$ & $\mathrm{Ph}$ & $\mathbf{1 c}$ & 6 & $\mathbf{2 c}$ & $(84)$ \\
4 & $4-\mathrm{NO}_{2} \mathrm{C}_{6} \mathrm{H}_{4}$ & $\mathrm{Ph}$ & $\mathbf{1 d}$ & 8 & $\mathbf{2 d}$ & $(83)$ \\
5 & $4-\mathrm{MeC}_{6} \mathrm{H}_{4}$ & $4-\mathrm{MeC}_{6} \mathrm{H}_{4}$ & $\mathbf{1 e}$ & 6 & $\mathbf{2 e}$ & 86 \\
6 & $\mathrm{Ph}$ & $\mathrm{Me}$ & $\mathbf{3 a}$ & 3 & $\mathbf{4 a}$ & trace \\
\hline
\end{tabular}

${ }^{a}$ Reaction conditions: $\mathrm{VOSO}_{4}(0.005 \mathrm{mmol}), 4,4^{\prime}-t$-Bubpy $(0.01 \mathrm{mmol})$, substrate $(0.1 \mathrm{mmol}), \mathrm{H}_{2} \mathrm{O}(0.5 \mathrm{~mL}), \mathrm{O}_{2}(0.1 \mathrm{MPa}), 90{ }^{\circ} \mathrm{C} .{ }^{b}$ Determined by ${ }^{1} \mathrm{H}$ NMR. Isolated yields are shown in parentheses.

for the $\mathrm{VOSO}_{4}$-catalyzed reaction (entry 6). A cursory examination of several bipyridyl derivatives in the oxidation reaction demonstrated that 4,4'-t-Bubpy was the most effective ligand (entries 7-15). Steric bulk around the ligand co-ordination site had varying effects on reaction efficiency; 6,6'-dimethyl-2,2'bipyridyl (6,6'-Mebpy) was ineffective (entry 7), most likely because approach of the substrate to the central metal was inhibited by the functional groups blocking the metal site.

Oxidation of other substrates using 4,4'-t-Bubpy as a ligand was also investigated under an atmosphere of $\mathrm{O}_{2}$ in water (Table 3). Benzhydrol derivatives (1) with an electron-donating or electron-withdrawing group could be oxidized to the corresponding carbonyl compounds in high yields (entries 1-5).

In the case of 1-phenylethanol (3a), however, the reaction proceeded ineffectively (Table 3 , entry 6). After further optimization of the reaction conditions, it was noticed that addition of a catalytic amount of 1a promoted the oxidation of the 3a; acetophenone (4a) was obtained in this manner in $22 \%$ yield (Table 4, entry 1). Furthermore, using sat. $\mathrm{MgSO}_{4}(\mathrm{aq})$ and scaling up substrate loading from $0.1 \mathrm{mmol}$ to $0.5 \mathrm{mmol}$

Table 4 Oxidation in the presence of benzhydrol additives ${ }^{a}$

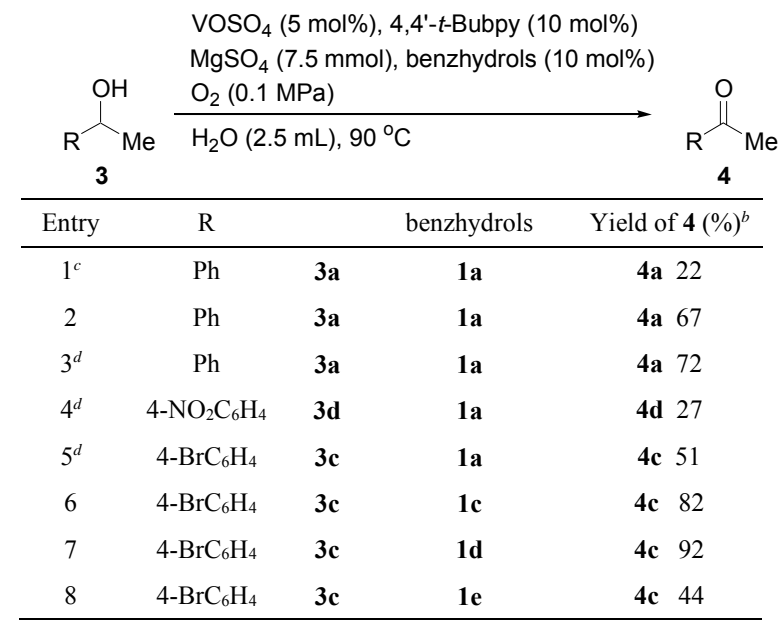

${ }^{a}$ Reaction conditions: $\mathrm{VOSO}_{4}(0.025 \mathrm{mmol}), 4,4^{\prime}-t$-Bubpy $(0.05 \mathrm{mmol})$, substrate $(0.5 \mathrm{mmol}), \mathrm{MgSO}_{4}(7.5 \mathrm{mmol}), \mathrm{H}_{2} \mathrm{O}(2.5 \mathrm{~mL}), \mathrm{O}_{2}(0.1 \mathrm{MPa}), 90$ ${ }^{\circ} \mathrm{C} .22 \mathrm{~h} .{ }^{b}$ Determined by ${ }^{1} \mathrm{H}$ NMR. ${ }^{c}$ Substrate $(0.1 \mathrm{mmol})$ in the absence of $\mathrm{MgSO}_{4}$, reaction time: $6 \mathrm{~h} .{ }^{d}$ Substrate $(1.0 \mathrm{mmol}), \mathrm{MgSO}_{4}(15 \mathrm{mmol})$.
Table 5. Time-course change of oxidation of $\mathbf{1} \mathbf{a}^{a}$

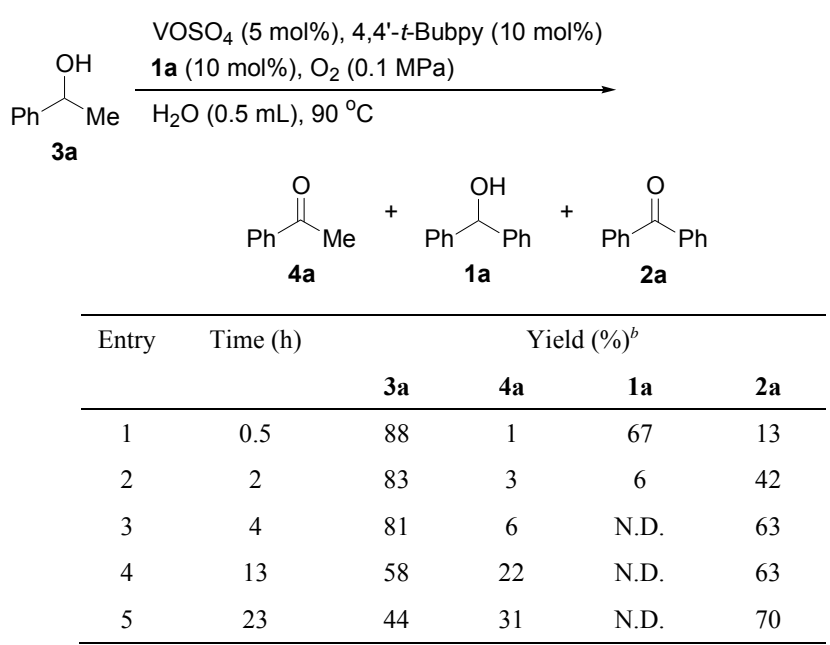

${ }^{a}$ Reaction conditions: $\mathrm{VOSO}_{4}(0.005 \mathrm{mmol}), 4,4^{\prime}-t-\operatorname{Bubpy}(0.01 \mathrm{mmol}), \mathbf{1 a}$ $(0.01 \mathrm{mmol}), \mathrm{H}_{2} \mathrm{O}(0.5 \mathrm{~mL})$, substrate $(0.1 \mathrm{mmol}), \mathrm{O}_{2}(0.1 \mathrm{MPa}), 90{ }^{\circ} \mathrm{C} .{ }^{b}$ Determined by ${ }^{1} \mathrm{H}$ NMR. N.D.: Not detected.

Table 6 Oxidation of benzyl alcohol derivatives under an $\mathrm{O}_{2}$ atmosphere $^{a}$

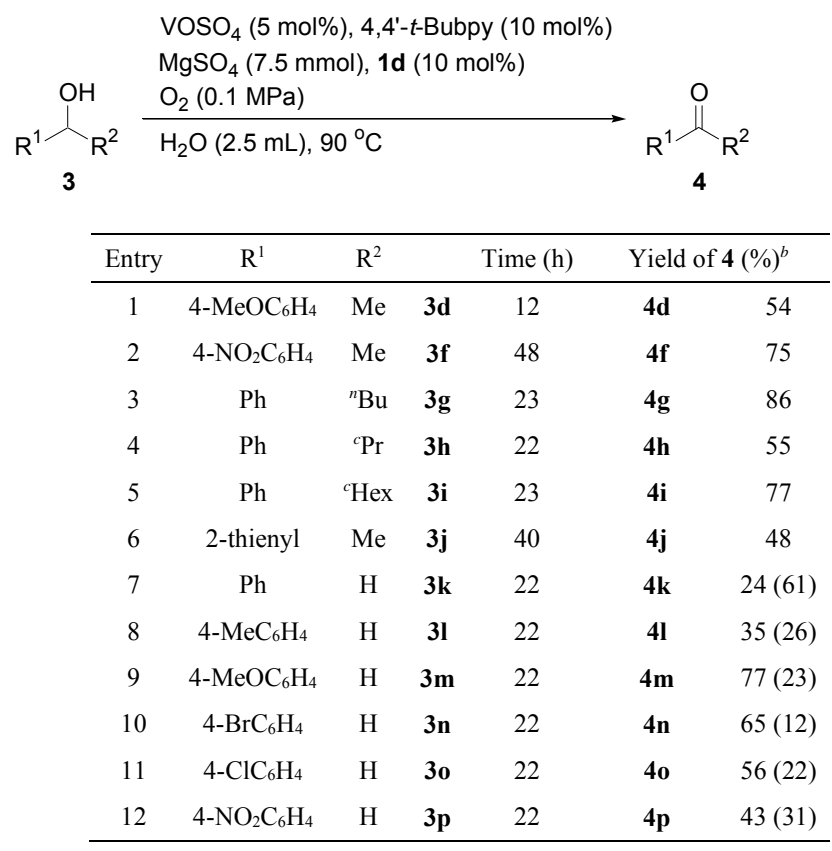

${ }^{a}$ Reaction conditions: $\mathrm{VOSO}_{4}(0.025 \mathrm{mmol}), 4,4^{\prime}-t-\mathrm{Bubpy}(0.05 \mathrm{mmol}), \mathbf{1 d}$ (0.05 mmol), $\mathrm{H}_{2} \mathrm{O}(2.5 \mathrm{~mL}), \mathrm{MgSO}_{4}(7.5 \mathrm{mmol})$, substrate $(0.5 \mathrm{mmol}), \mathrm{O}_{2}$ $(0.1 \mathrm{MPa}), 90{ }^{\circ} \mathrm{C} .{ }^{b}$ Determined by ${ }^{1} \mathrm{H}$ NMR. Yield of carboxylic acids are shown in parentheses.

improved reaction efficiency and yield of the desired product $(67 \%$, entry 2). Further substrate scale-up increased the product yield only minimally (entry 3 ). For oxidation of other benzyl alcohols, the benzhydrol additive was less effective (entries 4,5 ). Several benzhydrol derivatives were examined for the oxidation of $p$-bromo- $\alpha$-methylbenzyl alcohol (1h), with oxidation proceeding in moderate to high yields. It was apparent that $p$ nitrobenzhydrol (1d) was most effective as an additive in the present oxidation system, with the corresponding ketone obtained in $92 \%$ yield (entry 7 ).

Next, the time-course of the vanadium-catalyzed oxidation of 3a using catalytic 1a as an additive was investigated in further 
Scheme 4 Oxidation of 1a under open-air conditions in water

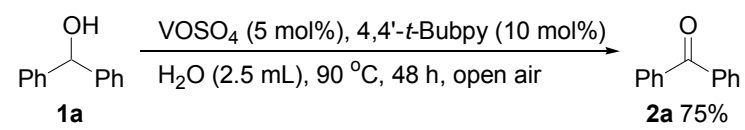

Scheme 5 Gram-scale oxidation of 1a under open-air conditions

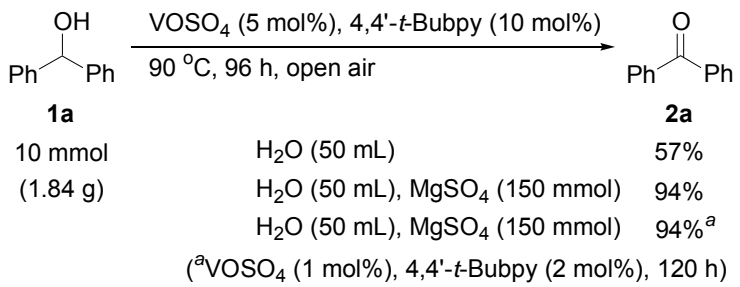

Table 7 Oxidation of benzhydrol derivatives under open airatmosphere $^{a}$

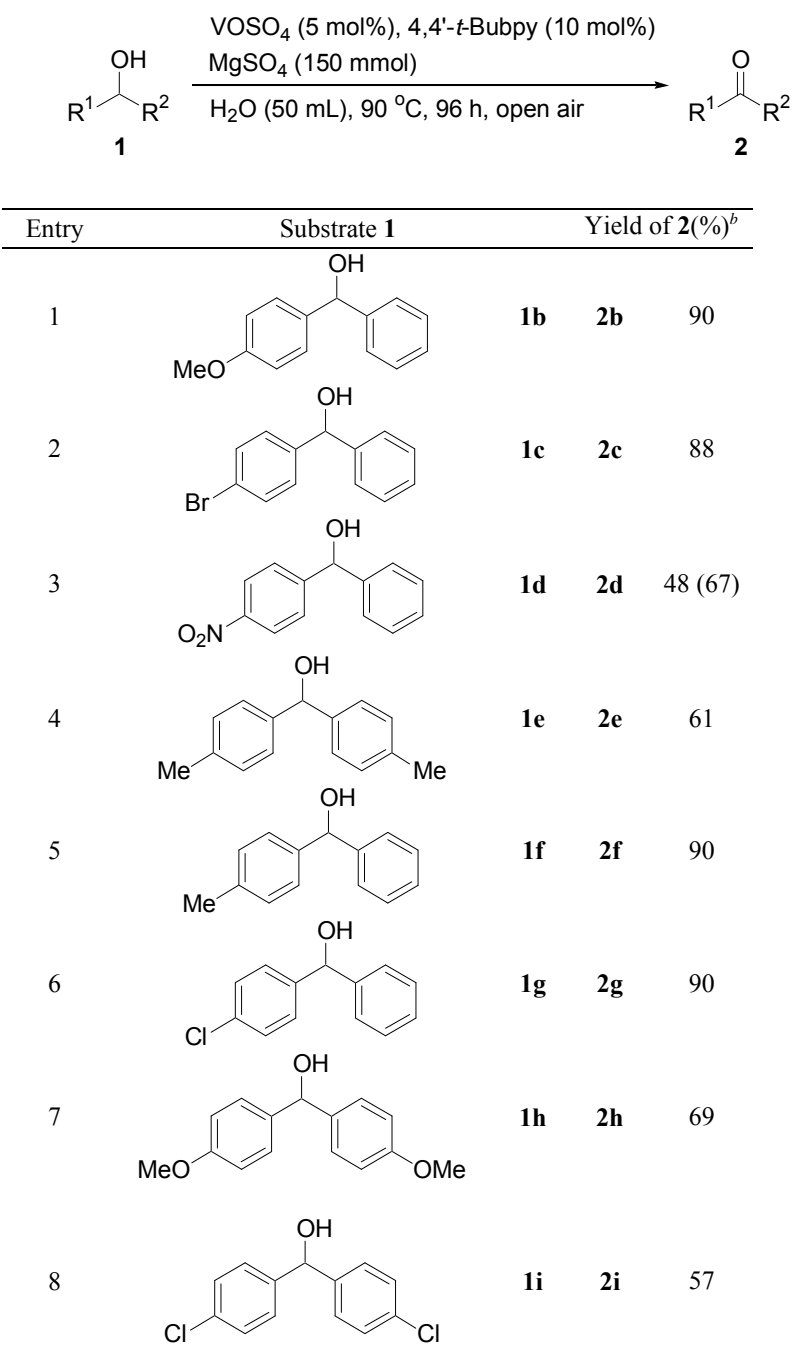

${ }^{a}$ Reaction conditions: $\mathrm{VOSO}_{4}(0.5 \mathrm{mmol}), 4,4^{\prime}-t$-Bubpy $(1 \mathrm{mmol}), \mathrm{H}_{2} \mathrm{O}$ $(50 \mathrm{~mL}), \mathrm{MgSO}_{4}(150 \mathrm{mmol})$, substrate $(10 \mathrm{mmol}), 90{ }^{\circ} \mathrm{C}$, open-air atmosphere. ${ }^{b}$ Isolated yield. ${ }^{1} \mathrm{H}$ NMR yields are shown in parentheses.

detail by $1 \mathrm{H} \mathrm{NMR}$ analysis. Over the reaction course, the yield of $\mathbf{4 a}$ continued to increase with the complete consumption of $\mathbf{1 a}$, which was oxidized to $\mathbf{2 a}$ (Table 5). The oxidation of $\mathbf{3 a}$ using
Table 8 Oxidation of secondary benzyl alcohol derivatives under open-air atmosphere ${ }^{a}$

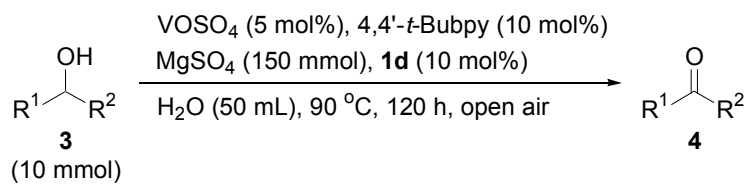

\begin{tabular}{lllll}
\hline Entry & Substrate 3 & Yield of $\mathbf{4}(\%)^{b}$ \\
\hline 1 & $\mathbf{3 g}$ & $\mathbf{4 g}$ & $83(88)$
\end{tabular}

2

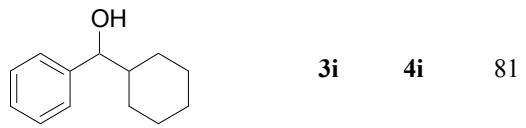

3

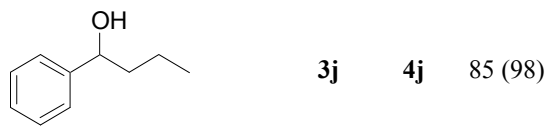

4

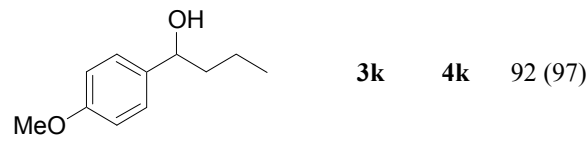

5

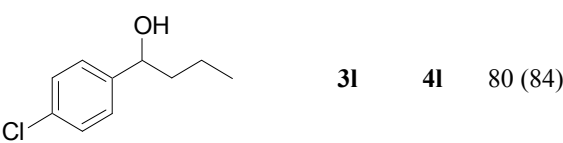

6

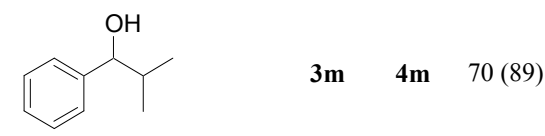

7

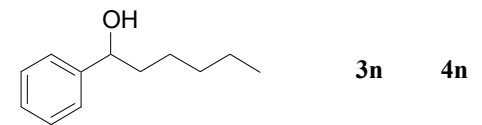

8

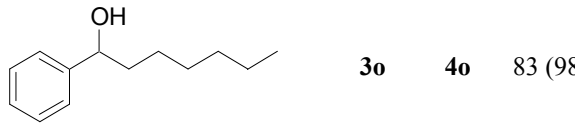

${ }^{a}$ Reaction conditions: $\mathrm{VOSO}_{4}(0.5 \mathrm{mmol}), 4,4^{\prime}-t$-Bubpy $(1 \mathrm{mmol}), \mathbf{1 d}(1$ $\mathrm{mmol}), \mathrm{H}_{2} \mathrm{O}(50 \mathrm{~mL}), \mathrm{MgSO}_{4}(150 \mathrm{mmol})$, substrate $(10 \mathrm{mmol}), 90^{\circ} \mathrm{C}$, openair atmosphere. ${ }^{b}$ Isolated yield. ${ }^{1} \mathrm{H}$ NMR yields are shown in parentheses.

2a as an additive was also investigated, but the reaction proceeded inefficientry. Furthermore, oxidation of $\mathbf{3 c}$ suggested that substituents on the aromatic ring of benzhydrol additives may affect the activity of the vanadium catalyst (See Table 4, entries 5-9). ${ }^{13}$

Oxidation of benzyl alcohol derivatives (3) was studied next using the optimized conditions (Table 6). Oxidation of secondary benzyl alcohols proceeded smoothly, with the corresponding ketones obtained in good to high yields (entries 16). Benzyl alcohols with electron-withdrawing groups required prolonged reaction times, giving the corresponding ketone in moderate yield (entry 2). This system could be applied to the oxidation of 1-(2-thienyl)ethanol (3j), a heterocyclic example; 2acetylthiophene ( $4 \mathbf{n})$ was obtained in $48 \%$ yield (entry 6 ).

We next applied our catalytic system to the oxidation ofbenzhydrol under an open-air atmosphere, the mildest possible condition in the oxidation reaction (Scheme 4). Interestingly, the oxidation proceeded successfully by prolonging the reaction time 
Table 9 Effect of salts on the oxidation of $\mathbf{1 a}^{a}$

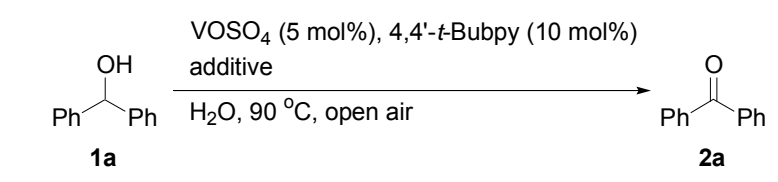

\begin{tabular}{cccc}
\hline Entry & Additive & Time $(\mathrm{h})$ & ${\text { Yield }(\%)^{b}}^{b}$ \\
\hline 1 & $\mathrm{MgSO}_{4}(7.5 \mathrm{mmol})$ & 48 & 24 \\
2 & $\mathrm{MgSO}_{4}(150 \mathrm{mmol})$ & 48 & 42 \\
3 & $\mathrm{NaCl}^{(330 \mathrm{mmol})}$ & 48 & $(11)$ \\
4 & $\mathrm{MgSO}_{4}(150 \mathrm{mmol})$ & 96 & 94 \\
5 & $\mathrm{Na}_{2} \mathrm{SO}_{4}(152 \mathrm{mmol})$ & 96 & $(80)$ \\
6 & $\left(\mathrm{NH}_{3}\right)_{2} \mathrm{SO}_{4}(150 \mathrm{mmol})$ & 96 & 43 \\
7 & $\mathrm{~K}_{2} \mathrm{SO}_{4}(150 \mathrm{mmol})$ & 96 & 73 \\
\hline
\end{tabular}

${ }^{a}$ Reaction conditions: $\mathrm{VOSO}_{4}(0.5 \mathrm{mmol}), 4,4^{\prime}-t$-Bubpy $(1 \mathrm{mmol}), \mathrm{H}_{2} \mathrm{O}$ (50 $\mathrm{mL}$ ), additive, benzhydrol $(10 \mathrm{mmol}), 90{ }^{\circ} \mathrm{C}$, open-air atmosphere. The amounts of additives were adjusted to be saturated in $90{ }^{\circ} \mathrm{C}$. ${ }^{b}$ Isolated yield. ${ }^{1} \mathrm{H}$ NMR yields are shown in parentheses.

to $48 \mathrm{~h}$; the corresponding ketone was successfully obtained in $75 \%$ yield.

Gram-scale aerobic oxidation of benzhydrol was also examined (Scheme 5). The oxidation proceeded to yield benzophenone in moderate yield (57\%). The addition of sat. $\mathrm{MgSO}_{4}$ (aq) to the reaction mixture allowed for benzophenone to be obtained in a vastly improved yield (94\%). Moreover, the oxidation was also proceeded efficiently, when the catalyst amount was reduced to $1 \mathrm{~mol} \%$.

From these results, gram-scale oxidations of benzhydrol derivatives under open-air conditions in sat. $\mathrm{MgSO}_{4}$ (aq) were performed. Stirring under open-air condition in water, the corresponding ketones were obtained in moderate to high yields (Table 7).

Gram-scale oxidation of benzyl alcohol derivatives was also investigated. Secondary benzyl alcohols were oxidized successfully in water under open air conditions and the corresponding ketones were obtained in high yields (Table 8). The procedure could also be successfully applied to alcohols having long-chained alkyl groups.

The effects of additives were studied. $\mathrm{VOSO}_{4}$ was soluble in water in our oxidation system; in contrast, the ligands and substrates were insoluble, and would float on the aqueous solution of vanadium. The complexation of vanadium with ligands began by heating the mixture, which melted the substrate; the vanadium complex was then able to solubilize in this organic phase. From these results, we presume that this oxidation proceeds in the organic layer composed of the substrate. To improve the efficiency of substrate contact with the vanadium complex, several salts were added to the reaction system; $\mathrm{MgSO}_{4}$ was found to be the most effective additive for solubilization in the established reaction system (Table 9). ${ }^{13}$

A plausible reaction pathway is proposed in Figure $1 .^{11 \mathrm{e}}$ Firstly, complex $\mathbf{A}$ is provided by the reaction of alcohol and catalyst. A is oxidized by molecular oxygen and generates $\mathrm{V}(\mathrm{V})$ species $\mathbf{B}$, and $\mathbf{C}$ is formed through intramolecular hydrogen abstraction. To corroborate this reaction pathway, we examined the catalyst complex via ${ }^{51} \mathrm{~V}$ NMR spectroscopy. A weak and broad peak was detected at ca. $\delta-510 \mathrm{ppm}$ in the ${ }^{51} \mathrm{~V}$ NMR spectrum $\left(\mathrm{CDCl}_{3}\right)$ of the mixture after reaction (See supporting
Figure 1. A plausible catalytic cycle

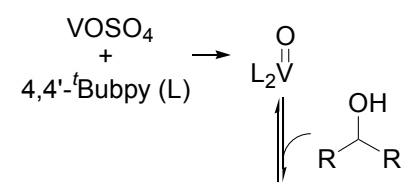

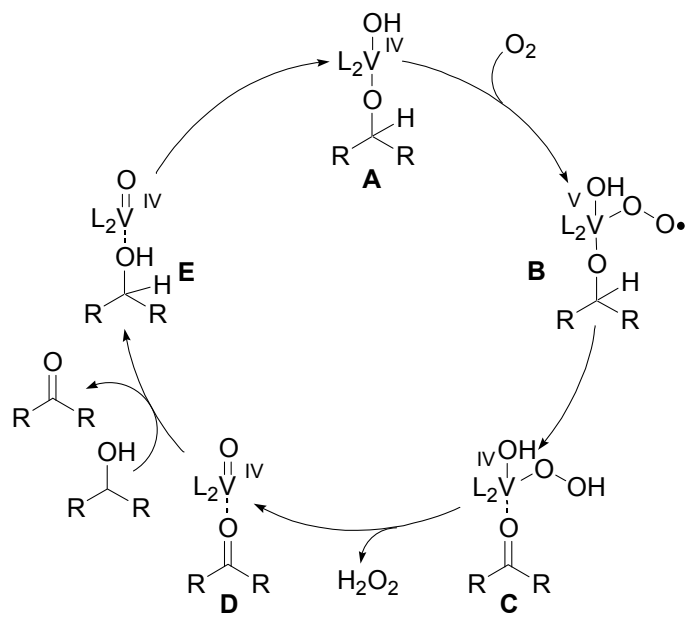

infomation). ${ }^{14}$ From this, we assume the formation of active catalytic $\mathrm{V}(\mathrm{V})$ species in this reaction. Elimination of $\mathrm{H}_{2} \mathrm{O}_{2}($ D) and ligand exchange of product by alcohol (E) completes the catalytic cycle. We suppose that benzhydrols may generate $\mathrm{H}_{2} \mathrm{O}_{2}$, as a more active oxidant than molecular $\mathrm{O}_{2}$, act as a ligand for the vanadium catalyst, or eliminate some active species to improve catalytic activity (See supporting infomation). ${ }^{15}$

\section{Conclusion}

In conclusion, we have developed a novel vanadium-catalyzed system for the oxidation of benzyl alcohol derivatives, using water as the sole solvent under atmospheric pressure of $\mathrm{O}_{2}$. Furthermore, oxidation proceeds under open-air atmosphere, and the corresponding carbonyl compounds are obtained in good yields. The advantages of our oxidation method are three-fold: (1) special devices such as autoclaves are unnecessary; (2) there is no cost for the oxidant, as air functions as the terminal oxidant; (3) the gram-scale oxidation of several alcohols proceeds efficiently using water as a benign reaction medium. Finally, because our oxidation method is safe, operationally simple, and amenable to gram-scale synthesis under an air atmosphere, we expect this novel vanadium-bipyridyl ligand complex to be useful for green oxidation in organic synthesis and low-costly industrial chemical applications.

\section{Experimental Section}

\section{General Information}

${ }^{1} \mathrm{H}$ NMR spectra were recorded on a JEOL JNM-ECX400 (400 $\mathrm{MHz}$ ) FT NMR system using $\mathrm{CDCl}_{3}$ as the solvent with tetrametylsilane (TMS) as the internal standard. ${ }^{13} \mathrm{C}$ NMR spectra were recorded on a JEOL JNM-ECX400 (100 MHz) FT NMR system using $\mathrm{CDCl}_{3}$ as the solvent. Alcohols were prepared by reduction of the corresponding ketones with $\mathrm{NaBH}_{4}$ (except 1a, 1f, 1g, 1h, 1i, 3j, and 3n,). Unless otherwise noted, other reactants and reagents were purchased from commercial source and used without further purification.

\section{General procedure of Synthesis of substrates ${ }^{16}$}

To a solution of ketone or aldehyde $(20.0 \mathrm{mmol})$ in $\mathrm{MeOH}(50$ $\mathrm{mL}$ ) (or a mixture of $\mathrm{MeOH}$ and $\mathrm{MeCN}$ ), $\mathrm{NaBH}_{4}(40 \mathrm{mmol}$ ) was 
added and stirred at room temperature. After confirming by TLC that the starting material was consumed entirely, the reaction mixture was poured into a separatory funnel, and organic layer was extracted with EtOAc. Extracted organic layers were washed with brine, and dried with anhydrous $\mathrm{MgSO}_{4}$, and concentrated to give the pure product.

\section{Synthesis of [VO(t-Bubpy $\left.)_{2}\right] \mathrm{SO}_{4}{ }^{17}$}

To a solution of 4,4'-di-tert-butyl-2,2'-bipyridyl (930.4 mg, $3.5 \mathrm{mmol})$ in EtOH $(40 \mathrm{~mL})$ was added a solution of $\mathrm{VOSO}_{4} \cdot 5 \mathrm{H}_{2} \mathrm{O}(437.6 \mathrm{mg}, 1.7 \mathrm{mmol})$ in $\mathrm{EtOH}(20 \mathrm{~mL})$. After stirring for $2.5 \mathrm{~h}$ at room temperature, the solution was concentrated under reduced pressure, and the precipitate was filtered using diethyl ether and dried in vacuo to afford $[\mathrm{VO}(t-$ Bubpy $)_{2} \mathrm{SO}_{4}$ as a green powder $(700.6 \mathrm{mg})$. HR-ESI MS $(\mathrm{MeOH})$ calcd for $\mathrm{C}_{36} \mathrm{H}_{49} \mathrm{~N}_{4} \mathrm{O}_{5} \mathrm{SV}[\mathrm{M}+\mathrm{H}]+700.2863$, found 700.2881 .

\section{Oxidation of benzhydrols with molecular oxygen}

Catalyst $(0.005 \mathrm{mmol})$, ligand $(0.01 \mathrm{mmol})$, and substrate $(0.1$ mmol) were placed in a $10 \mathrm{~mL}$ two necked flask, and then water $(0.5 \mathrm{~mL})$ was added. Next, the mixture was stirred at $90{ }^{\circ} \mathrm{C}$ for the appropriate time under $\mathrm{O}_{2}\left(0.1 \mathrm{MPa}, \mathrm{O}_{2}\right.$ balloon $)$. The yield of the product was confirmed by ${ }^{1} \mathrm{H}$ NMR spectroscopy using 1,2diphenylethane as the internal standard, after extraction of the reaction mixture with diethyl ether. Purification of the products was carried out by a short pad of silica gel using ethyl acetate and hexane as eluent to afford the analytically pure ketones. The products were identified by comparison with the commercially available samples.

\section{Oxidation of benzhyl alcohols with molecular oxygen}

$\mathrm{VOSO}_{4} \cdot 5 \mathrm{H}_{2} \mathrm{O}(6.3 \mathrm{mg}, 0.025 \mathrm{mmol}), 4,4^{\prime}$-di-tert-butyl-2,2'bipyridyl (13.4 mg, $0.05 \mathrm{mmol})$, and $p$-nitrobenzhydrol $(0.05$ mmol) were placed in a $25 \mathrm{~mL}$ two necked round-bottomed flask, and then water $(2.5 \mathrm{~mL})$ was added. Next, the mixture was stirred, and then anhydrous $\mathrm{MgSO}_{4}(902.8 \mathrm{mg}, 7.5 \mathrm{mmol})$ was slowly added into the mixture (cooling by ice water). Then, substrate $(0.5 \mathrm{mmol})$ was added into the mixture at room temperature, and the mixture was stirred at $90{ }^{\circ} \mathrm{C}$ for the appropriate time under $\mathrm{O}_{2}\left(0.1 \mathrm{MPa}, \mathrm{O}_{2}\right.$ balloon $)$. The yield of the product was confirmed by ${ }^{1} \mathrm{H}$ NMR spectroscopy using 1,2diphenylethane as the internal standard ${ }^{1} \mathrm{H}$ NMR spectroscopy using 1,2-diphenylethane as the internal standard, after extraction of the reaction mixture with diethyl ether. The product was identified by comparison with the commercially available sample.

\section{Oxidation of alcohols under open-air atmosphere}

$\mathrm{VOSO}_{4} \cdot 5 \mathrm{H}_{2} \mathrm{O}$ (126.5 mg, $\left.0.5 \mathrm{mmol}\right), 4,4^{\prime}$-di-tert-butyl-2,2'bipyridyl (268.4 mg, $1 \mathrm{mmol})$, and p-nitrobenzhydrol (229.3 $\mathrm{mg}$, $0.05 \mathrm{mmol}$ ) were placed in a $100 \mathrm{~mL}$ round-bottomed flask, and then water $(50 \mathrm{~mL})$ was added. Next, the mixture was stirred, and then anhydrous $\mathrm{MgSO}_{4}(18.06 \mathrm{~g}, 150 \mathrm{mmol})$ was slowly added into the mixture (cooling by ice water). After that, substrate $(10 \mathrm{mmol})$ was added into the mixture at room temperature, and the mixture was stirred at $90{ }^{\circ} \mathrm{C}$ for the appropriate time under open air atmosphere. After the reaction, the mixture was extracted with ethyl acetate and dried over anhydrous $\mathrm{MgSO}_{4}$. The extracts were concentrated in vacuo. Purification of the products was carried out by silica gel column chromatography using hexane and diethyl ether as eluent to afford the analytically pure ketones. In Table 7 (entries 3, 7 and 8 ), crude products were purified by recrystallization with ethyl acetate in refrigerator, afforded analytically pure ketones. The product was identified by comparison with the commercially available sample using ${ }^{1} \mathrm{H}$ NMR spectroscopy.

\section{Analytical Data.}

Benzophenone $^{18(\mathrm{a}), 18(\mathrm{~b}), 18(\mathrm{c})}$ (2a, Scheme 5). White solid; Mp 47$48{ }^{\circ} \mathrm{C}$; yield $1.7149 \mathrm{~g}(94 \%) ;{ }^{1} \mathrm{H}$ NMR $\left(400 \mathrm{MHz}, \mathrm{CDCl}_{3}\right) \delta$ $7.82-7.80(\mathrm{~m}, 4 \mathrm{H}), 7.62-7.58(\mathrm{~m}, 2 \mathrm{H}), 7.51-7.47(\mathrm{~m}, 4 \mathrm{H}) ;{ }^{13} \mathrm{C}$ NMR (100 MHz, $\left.\mathrm{CDCl}_{3}\right) \delta 196.7,137.6,132.4,130.0,128.2$

4-Methoxyphenyl(phenyl)methanone $\boldsymbol{e}^{18(\mathrm{~b}), 18(\mathrm{c}), 18(\mathrm{j})}$ (2b, Table 7). White solid; Mp 56-57 ${ }^{\circ} \mathrm{C}$; yield $1.9185 \mathrm{~g}(90 \%) ;{ }^{1} \mathrm{H}$ NMR (400 $\left.\mathrm{MHz}, \mathrm{CDCl}_{3}\right) \delta 7.82(\mathrm{~d}, J=7.3 \mathrm{~Hz}, 2 \mathrm{H}), 7.74(\mathrm{~d}, J=7.8 \mathrm{~Hz}$, 2H), 7.54-7.43 (m, 3H), 6.95 (d, $J=7.3 \mathrm{~Hz}, 2 \mathrm{H}), 3.85$ (s, 3H); ${ }^{13} \mathrm{C}$ NMR $\left(100 \mathrm{MHz}, \mathrm{CDCl}_{3}\right) \delta 195.4,163.1,138.2,132.4,131.8$, 129.6, 129.3, 128.1, 113.5, 55.4

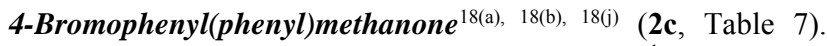
White solid; Mp 74-75 ${ }^{\circ} \mathrm{C}$; yield $2.2998 \mathrm{~g}(88 \%) ;{ }^{1} \mathrm{H}$ NMR (400 $\left.\mathrm{MHz}, \mathrm{CDCl}_{3}\right) \delta$ 7.77-7.74 (m, 2H), 7.67-7.56 (m, 5H), 7.49-7.45 $(\mathrm{m}, 2 \mathrm{H}) ;{ }^{13} \mathrm{C}$ NMR $\left(100 \mathrm{MHz}, \mathrm{CDCl}_{3}\right) \delta 195.4,137.0,136.2$, $132.6,131.5,131.4,129.8,128.3,127.4$

4-Nitrophenyl(phenyl)methanone ${ }^{18(\mathrm{~b}), 18(\mathrm{j})}$ (2d, Table 7). Yellow solid; Mp 136-137 ${ }^{\circ} \mathrm{C}$; yield $1.1009 \mathrm{~g}(48 \%) ;{ }^{1} \mathrm{H}$ NMR (400 $\left.\mathrm{MHz}, \mathrm{CDCl}_{3}\right) \delta 8.35(\mathrm{~d}, J=8.2 \mathrm{~Hz}, 2 \mathrm{H}), 7.94(\mathrm{~d}, J=8.2 \mathrm{~Hz}$, 2H), $7.81(\mathrm{~d}, J=7.3 \mathrm{~Hz}, 2 \mathrm{H}), 7.66$ (t, $J=7.3 \mathrm{~Hz}, 2 \mathrm{H}), 7.53$ (t, $J=$ $7.3 \mathrm{~Hz}, 2 \mathrm{H}) ;{ }^{13} \mathrm{C} \mathrm{NMR}\left(100 \mathrm{MHz}, \mathrm{CDCl}_{3}\right) \delta 194.8,149.8,142.9$, $136.3,133.5,130.7,130.1,128.7,123.5$

Bis(4-metylphenyl)methanone ${ }^{18(\mathrm{~d}), 18(\mathrm{k})}$ (2e, Table 7). White solid; Mp 87-88 ${ }^{\circ} \mathrm{C}$; yield $1.3044 \mathrm{~g}(61 \%)$; ${ }^{1} \mathrm{H}$ NMR (400 MHz, $\left.\mathrm{CDCl}_{3}\right) \delta 7.70(\mathrm{~d}, J=8.2 \mathrm{~Hz}, 4 \mathrm{H}), 7.27(\mathrm{~d}, J=8.2 \mathrm{~Hz}, 4 \mathrm{H}), 2.44$ $(\mathrm{s}, 6 \mathrm{H}) ;{ }^{13} \mathrm{C}$ NMR $\left(100 \mathrm{MHz}, \mathrm{CDCl}_{3}\right) \delta 196.2,142.9,135.2$, $130.2,128.9,21.6$

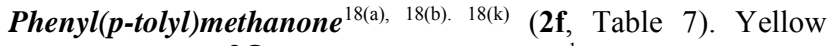
solid; Mp 52-53 ${ }^{\circ} \mathrm{C}$; yield $1.7642 \mathrm{~g} \mathrm{(90 \% );}{ }^{1} \mathrm{H}$ NMR (400 MHz, $\left.\mathrm{CDCl}_{3}\right) \delta$ 7.79-7,76 (m, 2H), 7.73-7.71 (d, J=8.2 Hz, 2H), 7.587.54 (tt, $J=7.3 \mathrm{~Hz}, 1.37 \mathrm{~Hz}, 1 \mathrm{H}), 7.48-7.44(\mathrm{~m}, 2 \mathrm{H}), 7.27$ (d, $J=$ $7.3 \mathrm{~Hz}, 2 \mathrm{H}), 2.43(\mathrm{~s}, 3 \mathrm{H}) ;{ }^{13} \mathrm{C} \mathrm{NMR}\left(100 \mathrm{MHz}, \mathrm{CDCl}_{3}\right) \delta 196.4$, 143.2, 137.9, 134.8, 132.1, 130.2, 129.9, 128.9, 128.1, 21.6

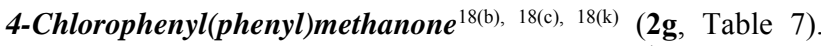
White solid; Mp 70-71 ${ }^{\circ} \mathrm{C}$; yield $1.9627 \mathrm{~g}(90 \%) ;{ }^{1} \mathrm{H}$ NMR $(400$ $\left.\mathrm{MHz}, \mathrm{CDCl}_{3}\right) \delta$ 7.79-7.74 (m, 4H), 7.62-7.57 (m, 1H), 7.51-7.44 $(\mathrm{m}, 4 \mathrm{H}) ;{ }^{13} \mathrm{C}$ NMR $\left(100 \mathrm{MHz}, \mathrm{CDCl}_{3}\right) \delta 195.4,138.8,137.2$, $135.8,132.6,131.4,129.9,128.6,128.3$

Bis(4-methoxyphenyl)methanone ${ }^{18(\mathrm{c}), 18(1)}$ (2h, Table 7). White solid; Mp 143-144 ${ }^{\circ} \mathrm{C}$; yield $1.6673 \mathrm{~g}(69 \%)$; ${ }^{1} \mathrm{H}$ NMR (400 $\left.\mathrm{MHz}, \mathrm{CDCl}_{3}\right) \delta 7.78(\mathrm{~d}, J=7.3 \mathrm{~Hz}, 4 \mathrm{H}), 6.95(\mathrm{~d}, J=7.3 \mathrm{~Hz}$, 4H), $3.87(\mathrm{~s}, 6 \mathrm{H}) ;{ }^{13} \mathrm{C}$ NMR (100 MHz, $\left.\mathrm{CDCl}_{3}\right) \delta 194.3,162.7$, $132.1,130.6,113.3,55.3$

Bis(4-chlorophenyl)methanone ${ }^{18(\mathrm{c}),} \quad 18(\mathrm{k}) \quad(\mathbf{2 i}$, Table 7). White solid; Mp 142-143 ${ }^{\circ} \mathrm{C}$; yield $1.4536 \mathrm{~g}(57 \%) ;{ }^{1} \mathrm{H}$ NMR (400 $\left.\mathrm{MHz}, \mathrm{CDCl}_{3}\right) \delta 7.73(\mathrm{~d}, \mathrm{~J}=8.7 \mathrm{~Hz}, 4 \mathrm{H}), 7.47$ (d, J = 8.2 Hz, 4H); ${ }^{13} \mathrm{C}$ NMR $\left(100 \mathrm{MHz}, \mathrm{CDCl}_{3}\right) \delta 194.2,139.1,135.5,131.3,128.8$

1-Phenylpentan-1-one ${ }^{18(\mathrm{~g})}$ (4g, Table 8). Colorless oil; yield $1.3454 \mathrm{~g}(83 \%) ;{ }^{1} \mathrm{H}$ NMR $\left(400 \mathrm{MHz}, \mathrm{CDCl}_{3}\right) \delta$ 7.94-7.92 (m, 2H), 7.51-7.47 (m, 1H), 7.42-7.38 (m, 2H), $2.91(\mathrm{t}, J=7.3 \mathrm{~Hz}$, 2H) 1.69 (quint, $J=7.3 \mathrm{~Hz}, 2 \mathrm{H}$ ), 1.38 (sextet, $J=7.3 \mathrm{~Hz}, 2 \mathrm{H}$ ) $0.93(\mathrm{t}, J=7.3 \mathrm{~Hz}, 3 \mathrm{H}) ;{ }^{13} \mathrm{C}$ NMR $\left(100 \mathrm{MHz}, \mathrm{CDCl}_{3}\right) \delta 199.8$, $136.7,132.4,128.1,127.6,37.8,26.0,22.1,13.6$

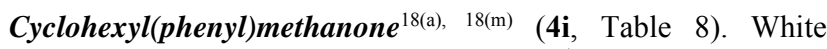
solid; Mp 54-55 ${ }^{\circ} \mathrm{C}$; yield $1.519 \mathrm{~g}(81 \%) ;{ }^{1} \mathrm{H}$ NMR (400 MHz, $\left.\mathrm{CDCl}_{3}\right) \delta$ 7.81-7.78 (m, 2H), 7.38-7.25 (m, 3H), 3.15-3.08 (m, 
$1 \mathrm{H}), 1.75-1.06(\mathrm{~m}, 10 \mathrm{H}) ;{ }^{13} \mathrm{C} \mathrm{NMR}\left(100 \mathrm{MHz}, \mathrm{CDCl}_{3}\right) \delta 203.2$, $135.9,132.3,128.2,127.9,45.1,29.0,25.6,25.5$

1-Phenylbutan-1-one ${ }^{18(\mathrm{e}), 18(\mathrm{f})}(\mathbf{4 j}$, Table 8$)$. Colorless oil; yield $1.2568 \mathrm{~g}(85 \%) ;{ }^{1} \mathrm{H}$ NMR $\left(400 \mathrm{MHz}, \mathrm{CDCl}_{3}\right) \delta 7.97-7.95(\mathrm{~m}$, 2H), 7.58-7.53 (m, 1H), 7.48-7.44 (m, 2H), 2.95 (t, J = 7.3, 2H), 1.78 (sextet, $\mathrm{J}=7.3,2 \mathrm{H}), 1.01(\mathrm{t}, \mathrm{J}=7.3,3 \mathrm{H}) ;{ }^{13} \mathrm{C}$ NMR $(100$ $\left.\mathrm{MHz}, \mathrm{CDCl}_{3}\right) \delta 199.8,136.8,132.5,128.2,127.7,40.1,17.4$, 13.5

1-(4-Methoxyphenyl)butan-1-one ${ }^{18(\mathrm{e})}$ (4k, Table 8). Yellow oil; yield $1.630 \mathrm{~g}(92 \%) ;{ }^{1} \mathrm{H}$ NMR $\left(400 \mathrm{MHz}, \mathrm{CDCl}_{3}\right) \delta 7.93(\mathrm{~d}, J=$ $8.7 \mathrm{~Hz}, 2 \mathrm{H}), 6.91(\mathrm{~d}, J=8.7 \mathrm{~Hz}, 2 \mathrm{H}), 3.83(\mathrm{~s}, 3 \mathrm{H}), 2.87(\mathrm{t}, \mathrm{J}=$ $7.3 \mathrm{~Hz}, 2 \mathrm{H}), 1.75$ (sixtet, $J=7.3 \mathrm{~Hz}, 2 \mathrm{H}), 0.99(\mathrm{t}, \mathrm{J}=7.3 \mathrm{~Hz}$, $3 \mathrm{H}) ;{ }^{13} \mathrm{C}$ NMR $\left(100 \mathrm{MHz}, \mathrm{CDCl}_{3}\right) \delta 198.7,163.1,130.0,130.0$, $113.4,55.2,39.9,17.8,13.7$

1-(4-Chlorophenyl)butan-1-one 18(f), $^{18(\mathrm{n})}$ (4l, Table 8). White solid; Mp 36-37 ${ }^{\circ} \mathrm{C}$; yield $1.9185 \mathrm{~g}(90 \%)$; ${ }^{1} \mathrm{H}$ NMR (400 MHz, $\left.\mathrm{CDCl}_{3}\right) \delta 7.89(\mathrm{~d}, J=8.2 \mathrm{~Hz}, 2 \mathrm{H}), 7.42(\mathrm{~d}, J=8.2 \mathrm{~Hz}, 2 \mathrm{H}), 2.91$ $(\mathrm{t}, \mathrm{J}=6.9 \mathrm{~Hz}, 2 \mathrm{H}), 1.76$ (sextet, $\mathrm{J}=7.3 \mathrm{~Hz}, 2 \mathrm{H}), 1.00$ (t, J = 7.3 $\mathrm{Hz}, 3 \mathrm{H}) ;{ }^{13} \mathrm{C}$ NMR $\left(100 \mathrm{MHz}, \mathrm{CDCl}_{3}\right) \delta 199.0,139.2,135.3$, $129.4,128.8,40.4,17.6,13.7$

2-methy-1-Phenyllpropan-1-one $\boldsymbol{~}^{18(\mathrm{~g}),} \quad{ }^{18(\mathrm{~h})} \quad \mathbf{( 4 \mathrm { m }}, \quad$ Table 8$)$. Colorless oil; yield $1.3454 \mathrm{~g}(70 \%) ;{ }^{1} \mathrm{H}$ NMR (400 MHz, $\left.\mathrm{CDCl}_{3}\right)$

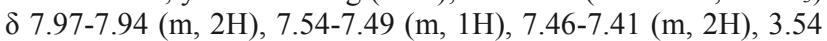
(sept, $J=6.9 \mathrm{~Hz}, 1 \mathrm{H}), 1.20(\mathrm{~d}, J=6.9 \mathrm{~Hz}, 6 \mathrm{H}) ;{ }^{13} \mathrm{C}$ NMR $(100$ $\left.\mathrm{MHz}, \mathrm{CDCl}_{3}\right) \delta 204.1,136.0,132.6,128.4,128.1,35.1,18.9$

1-Phenylheptan-1-one ${ }^{18(\mathrm{i})}$ (4o, Table 8). Colorless oil; yield $1.069 \mathrm{~g}(83 \%) ;{ }^{1} \mathrm{H}$ NMR $\left(400 \mathrm{MHz}, \mathrm{CDCl}_{3}\right) \delta$ 7.97-7.95 (m, 2H), 7.57-7.53 (m, 1H), 7.47-7.44 (m, 2H) $2.96(\mathrm{t}, J=7.3 \mathrm{~Hz}, 2 \mathrm{H})$, 1.74 (quint, $J=7.3 \mathrm{~Hz}, 2 \mathrm{H}), 1.40-1.30(\mathrm{~m}, 6 \mathrm{H}) 0.89(\mathrm{t}, J=6.9$ $\mathrm{Hz}, 3 \mathrm{H}) ;{ }^{13} \mathrm{C}$ NMR $\left(100 \mathrm{MHz}, \mathrm{CDCl}_{3}\right) \delta 200.6,137.1,132.8$, $128.5,128.0,38.6,31.7,29.0,24.3,22.5,14.0$

\section{Acknowledgment}

This research was supported by JST Research Seed Quest Program (Lower Carbon Society), from the Ministry of Education, Culture, Sports, Science, and Technology Promotion (KRF). S.K. acknowledges Research Fellowship of Japan Society for the Promotion of Science (JSPS) for Young Scientists.

\section{References and notes}

1. (a) M. Musawir, P. N. Davey, G. Kelly, I. V. Kozhevnikov, Chem. Commun., 2003, 1414; (b) T. Mallat, A. Baiker, Catal. Today, 1994, 19, 247; (c) R. A. Seldon, J. K. Kochi, Metal-Catalyzed Oxidation of Organic Compounds, Academic Press, New York, 1981; (c) N. Mizuno, K. Kamata, Coord. Chem. Rev., 2011, 255, 2358; (d) N. Mizuno, K. Kamata, K. Yamaguchi, Top. Catal., 2010, 53,876; (e) S. De Sarkar, A. Biswas, R. C. Samanta, A. Studer, Chem. Euro. J., 2013, 19, 4664; (f) L. Tebben, A. Studer, Angew. Chem., Int. Ed., 2011, 50, 5034; (g) H. Tsunoyama, H. Sakurai, Y. Negishi, T. Tsukuda, J. Am. Chem. Soc., 2005, 127, 9374. (h) A. Kamimura, Y. Nozaki, M. Nishiyama, M. Nakayama RSC Adv. 2013, 3, 468; (i) A. Kamimura, H. Komatsu, T. Moriyama, Y. Nozaki Tetrahedron 2013, 69, 5968; (j) Y. Ishii, S. Sakaguchi, T. Iwahama Adv. Synth. Catal. 2004, 343, 393

2. Numerous catalytic systems that use transition metals such as $\mathrm{Fe},{ }^{2} \mathrm{Cu},{ }^{3}$ $\mathrm{Mn},{ }^{4} \mathrm{Au},{ }^{5} \mathrm{Ru},{ }^{6}$ and $\mathrm{Pd}^{7}$ have been reported. However, most of these systems have several problems such as harsh reaction conditions and toxicity of the metal. (a) A. Al-Hunaiti, T. Niemi, A. Sibaouih, P. Pihko, M. Leskelä, T. Repo, Chem. Commun. 2010, 46, 9250; (b) B. Biswas, A. Al-Hunaiti, M. T. Räisänen, S. Ansalone, M. Leskelä, T. Repo, Y.-T. Chen, H.-L. Tsai, A. D. Naik, A. P. Raillet, Y. Garcia, R. Ghosh, N. Kole, Eur. J. Inorg. Chem. 2012, 4479; (c) S. E. Martin, A. Garrone, Tetrahedron Lett. 2003, 44, 549; (d) L. Wang, J. Li, G. Zhao, S. Gao, Appl. Organometal. Chem. 2012, 26, 37.

3. (a) I. E. Markó, P. R. Giles, M. Tsukazaki, S. M. Brown, C. J. Urch, Science, 1996, 274, 2044; (b) P. Chaudhuri, M. Hess, J. Müller, K.
Hildenbrand, E. Bill, T. Weyhermüller, K. Wieghardt, J. Am. Chem. Soc., 1999, 121, 9599; (c) G. Ferguson, A. N. Ajjou, Tetrahedron Lett., 2003, 44, 9139; (d) S. Velusamy, T. Punniyamurthy, Eur. J. Org. Chem., 2003, 3913; (e) T. Chattopadhyay, M. Kogiso, M. Asakawa, T. Shimizu, M. Aoyagi, Catal. Commun. 2010, 12, 9; (f) J. U. Ahmad, M. T. Räisänen, M. Leskelä, T. Repo, Appl. Catal. A: Gen., 2012, 411-412, 180; (g) I. E. Markó, A. Gautier, R. Dumeunier, K. Doda, F. Philippart, S. M. Brown, C. J. Urch, Angew. Chem. Int. Ed., 2004, 43, 1588.

4. (a) J. Brinksma, M. T. Rispens, R. Hage, B. L. Feringa, Inorg. Chim. Acta, 2002, 337, 75; (b) M. Bagherzadeh, Tetrahedron Lett., 2003, 44, 8943; (c) H.-K. Kwong, P.-K. Lo, K.-C. Lau, T.-C. Lau, Chem. Commun., 2011, 47, 4273.

5. (a) B. Guan, D. Xing, G. Cai, X. Wan, N. Yu, Z. Fang, L. Yang, Z. Shi, J. Am. Chem. Soc., 2005, 127, 18004; (b) H. Tsunoyama, T. Tsukuda, H. Sakurai, Chem. Lett., 2007, 36, 212; (c) A. Tanaka, K. Hashimoto, H. Kominami, J. Am. Chem. Soc., 2012, 134, 14526.

6. (a) A. Dijksman, A. Marino-Gonzalez, A. Mariata i Payeras, I. W. C. E. Arends, R. A. Sheldon, J. Am. Chem. Soc., 2001, 123, 6826; (b) N. Zotova, K. Hellgardt, G. H. Kelsall, A. S. Jessiman, K. K. Hii, Green Chem., 2010, 12, 2157; (c) H. Guo, W.-D. Liu, G. Yin, Appl. Organometal. Chem., 2011, 25, 836; (d) M. Rueping, C. Vila, A. Szadkowska, R. M. Koneigs, J. Fronert, ACS Catal., 2012, 2, 2810; (e) S.-S. Wang, J. Zhang, C.-L. Zhou, G. Vo-Thanh, Y. Liu, Catal. Commun., 2012, 28, 152 .

7. (a) B. M. Choudary, N. P. Reddy, M. L. Kantam, Z. Jamil, Tetrahedron Lett., 1985, 26, 6257; (b) G. Barak, J. Dakka, Y. Sasson, J. Org. Chem., 1988, 53, 3553; (c) K. P. Peterson, R. C. Larock, J. Org. Chem., 1998, 63, 3185; (d) C. Berini, D. F. Brayton, C. Mocka, O. Navarro, Org. Lett., 2009, 11, 4244; (e) C. Melero, O. N. Shishiov, E. Álvarez, P. Palma, J. Cámpora, Dalton Trans., 2012, 41, 14087.

8. (a) R. N. Butler, A. G. Coyne, Chem. Rev., 2010, 110, 6302; (b) A. Chanda, V. V. Fokin, Chem, Rev., 2009, 109, 725; (c) K. H. Shaughnessy, Chem. Rev., 2009, 109, 643. (d) S. Shimizu, N. Shimada, Y, Sasaki, Green Chem. 2006, 8, 608 .

9. (a) G.-J. Ten Brink, I. W. C. E. Arends, R. A. Sheldon, Science, 2000, 287, 1636; (b) B. P. Buffin, J. P. Clarkson, N. L. Belitz, A. Kundu, J. Mol. Catal. A: Chem., 2005, 225, 111; (c) T. Osako, Y. Uozumi, Chem. Lett., 2009, 38, 902; (d) N. Komiya, T. Nakae, H. Sato, T. Naota, Chem. Commun., 2006, 4829; (e) C. N. Kato, A. Shinohara, N. Moriya, K. Nomiya, Catal. Commun., 2006, 7, 413; (f) P. J. Figiel, M. Leskelä, T. Repo, Adv. Synth. Catal., 2007, 349, 1173; (g) H. Li, B. Guan, W. Wang, D. Xing, Z. Fang, X. Wan, L. Yang, Z. Shi, Tetrahedron, 2007, 63, 8430 .

10. (a) K. Kikushima, T. Moriuchi, T. Hirao Tetrahedron 2010, 66, 6906; (b) T. Sakamoto, T. Takagaki, A. Sakakura, Y. Obora, S. Sakaguchi, Y. Ishii J. Mol. Catal. A: Chem. 2008, 288, 19; (c) T. Nakai, T. Iwai, M. Mihara, T. Ito, T. Mizuno Tetrahedron Lett. 2010, 51, 2225.

11. (a) M. Kirihara, Y. Ochiai, S. Takizawa, H. Takahata, H. Nemoto, Chem. Commun., 1999, 1387; (b) Y. Maeda, N. Kakiuchi, S. Matsumura, T. Nishimura, S. Uemura, Tetrahedron Lett., 2001, 42, 8877; (c) Y. Maeda, N. Kakiuchi, S. Matsumura, T. Nishimura, T. Kawamura, S. Uemura, J. Org. Chem., 2002, 67, 6718; (d) S. Velusamy, T. Punniyamurthy, Org. Lett., 2004, 6, 217; (e) S. R. Reddy, S. Das, T. Punniyamurthy, Tetrahedron Lett., 2004, 45, 3561; (f) A. T. Radosevich, C. Musich, F. D. Toste, J. Am. Chem. Soc., 2005, 127, 1090; (g) Z. Du, H. Maio, H. Ma, Z. Sun, J. Ma, J. Xu, Adv. Synth. Catal., 2009, 351, 558; (h) N. Jiang, A. J. Ragauskas, Tetrahedron Lett. 2007, 48, 273; (i) Z. Du, j. Ma, H. Ma, J. Gao, J. Xu, Green Chem., $2010, \mathbf{1 2}, 590$

12. (a) M. Nakai, M. Obata, F. Sekiguchi, M. Kato, M. Shiro, A. Ichimura, I Kinoshita, M. Mikuriya, T. Inohara, K. Kawabe, H. Sakurai, C. Orvig, S Yano, J. Inorg. Biochem., 2004, 98, 105; (b) S. Kodama, Y. Ueta, J. Yoshida, A. Nomoto, S. Yano, M. Ueshima, A. Ogawa, Dalton Trans., 2009, 9708; (c) S. Kodama, J. Yoshida, A. Nomoto, Y. Ueta, S. Yano, M. Ueshima, A. Ogawa, Tetrahedron Lett. 2010, 51, 2450; (d) S. Kodama, A. Nomoto, S. Yano, M. Ueshima, A. Ogawa, Inorg. Chem., 2011, 50, 9942; (e) S. Kodama, S. Hashidate, A. Nomoto, S. Yano, M. Ueshima, A. Ogawa, Chem. Lett. 2011, 40, 495.

13. We suppose that sat. $\mathrm{MgSO}_{4}$ (aq) as solvent to improve the contact of catalyst and substrates; however, there is possibility that a high concentration of $\mathrm{SO}_{4}{ }^{2-}$ or $\mathrm{Mg}^{2+}$ is desirable in this reaction system.

14. (a) D. Render Bull. Magn. Reson. 1982, 4, 33; (b) M. R. Maurya, M. Bisht, A. Kumar, M. L. Kuznetsov, F. Avecilla, J. Costa Pessoa Dalton Trans. 2011, 40, 6968; (c) P. Adão, M. L. Kuznetsov, A. M. Martins, F. Avecilla, J. Costa Pessoa Inorg. Chem. 2012, 51, 11430; (d) N. Hall, M. Orio, A. Jorge-Robin, B. Gennaro, C. Marchi-Delapierre, C. Duboc Inorg. Chem. 2013, 52, 13424; (e) M. Debnath, A. Dutta, S. Biswas, K. K. Das, H. M. Lee, J. Vícha, R. Marek, J. Marek, M. Ali Polyhedron $2013, \mathbf{6 3}, 189$ 
15. K. Kamae, Y. Obora, Y. Ishii Bull. Chem. Soc. Jpn. 2009, 82, 891.

16. (a) R. Popielarz, D. R. Arnold, J. Am. Chem. Soc. 1990, 112, 3068; (b)

Y.-X. Liao, C.-H. Xing, P. He, Q.-S. Hu, Org. Lett. 2008, 10, 2509; (c)

T. Yamamoto, T. Ohta, Y. Ito, Org. Lett. 2005, 7, 4153; (d) R. Lerebours, C. Wolf, J. Am. Chem. Soc. 2006, 128, 13052; (e) L. Cao, J. Ding, M. Gao, Z. Wang, J. Li, A. Wu, Org. Lett. 2009, 11, 3810; (f) S. Liu, C. Wolf, Org. Lett. 2007, 9, 2965; (g) M. Noji, T. Ohno, K. Fuji, N. Futaba, H. Tajima, K. Ishii, J. Org. Chem.2003, 68, 9340; (h) M. B. Runge, M. T. Mwangi, A. L., II. Miller, M. Perring, N. B. Bowden, Angew. Chem., Int. Ed. 2008, 47, 935; (i) M. Kuriyama, R. Shimazawa, R. Shirai, J. Org. Chem. 2008, 73, 1597.

17. (a) M. Salavati-niasari, M. R. Elzami, M. R. Mansournia, S. Hydarzadeh J. Mol. Catal. A: Chem. 2004, 221, 169; (b) E. S. Bazhina, M. E. Nikiforova, G. G. Aleksandrov, N. N. Efimov, H. A. Ugolkova, O. M. Nikitin, T. V. Magdesieva, A. S. Bogomyakov, V. V. Minin, A. A. Sidorov, V. M. Novotortsev, I. L. Eremenko Inorg. Chim. Acta 2012, 392, 192.

18. (a) A. T. Biju, F Glorius Angew. Chem. Int. Ed. 2010, 49, 9761; (b) J. Karthikeyan, K. Parthasarathy, C.-H. Cheng Chem. Commun. 2011, 47, 10461; (c) H. Li, Y. Xu, E. Shi, W. Wei, X. Suo, X. Wan Chem. Commun. 2011, 47. 7880; (d) L. J. Goossen, C. Linder, N. Rodríguez, P. P. Lange Chem. Eur. J. 2009, 15, 9336; (e) J. Ruan, X. Li, O. Saidi, J. Xiao J. Am. Chem. Soc. 2008, 130, 2424; (f) Y. Liu, B. Yao, C.-L. Deng, R.-Y. Tang, X.-G. Zhang, J.-H. Li Org. Lett. 2011, 13, 2184; (g) D. T. Genna, G. H. Posner Org. Lett. 2011, 13, 5358; (h) K. Moriyama, M. Takemura, H. Togo Org. Lett. 2012, 14, 2414; (i) H. Lebel, C. Ladjel J. Org. Chem. 2005, 70, 10159; (j) B. Zhao, X. Li Org. Lett. 2006, 8, 5987; (k) S. Ushijima, S. Dohi, K. Moriyama, H. Togo Tetrahedron 2012, 68, 1436; (1) L. Yang, T. Zeng, Q. Shuai, X. Guo, C.-J. Li Chem. Commun. 2011, 47, 2161; (m) Á. Gutiérrez-Bonet, A. Flore-Gasper, R. Martin J. Am. Chem. Soc. 2013, 135, 12576; (n) P. J. Wagner, J. H. Sedon, A. Gudmundsdottir J. Am. Chem. Soc. 1996, 118, 746 


\section{Graphical Abstract}

\section{Vanadium-Catalyzed Green Oxidation of Benzylic Alcohols in Water under Air Atmosphere}

Kuniaki Marui,$\uparrow$ Yuuki Higashiura, $\uparrow$ Shintaro Kodama,$\uparrow$ Suguru Hashidate, $\uparrow$ Akihiro Nomoto,$\uparrow$ Shigenobu Yano, $\ddagger$ Michio Ueshima, $\uparrow$ and Akiya Ogawa*,$\dagger$

$$
\stackrel{\mathrm{VOSO}_{4}(5 \mathrm{~mol} \%), 4,4 \text {-t-Bubpy (10 mol\%) }}{\mathrm{O}_{2} \text { or Air }(0.1 \mathrm{MPa})}
$$

